\title{
Transformation of Traditional Village Architectural Values in Modern Sustainable Architecture Design
}

\author{
L. Widaningsih, D. Cahyani \\ Departement of Architectural Education \\ Faculty of Technical and Vocational Education \\ Universitas Pendidikan Indonesia \\ Bandung, Indonesia \\ liswidaningsih@yahoo.co.id
}

\begin{abstract}
This study is aim to explore the local wisdom of traditional villages as well as how these values can be an architecture precedent in the modern society in the sustainable architecture discourse. Therefore, the expected result is a description and application of the community education values of architecture. The method used is Research and Development with Participatory Action Research (PAR) model. The main data collection techniques are observation, focus group discussion (FGD), and face-to-face questionnaire survey to households. Aspects of implementation of architectural value are including building site management and environmental management, as well as building technique (building material usage and construction systems). Environmental education can be developed related to site and environmental management is to strengthen the habit of local people who develop the natural potential for everyday life. Traditional village precedent can be applied extent of the pattern of building technique, togetherness, as well as residential land use patterns. Meanwhile, technological transformation in the application building technique is how the design concept, the building functional needs and artisan work patterns can be communicated through the empowerment approach. The building technique aspects, in general, people prefer to build buildings that are technically easier and low cost, no longer consider aspects traditional custom inherited. The use of natural materials with traditional building construction in addition considered hard to find and expensive, the selection of manufacturing materials with a permanent building is considered more indicative of socioeconomic status.
\end{abstract}

Keywords—traditional village, modern sustainable architecture

\section{INTRODUCTION}

\section{A. Background}

Building and residential neighborhood regularity in traditional village community provides lessons that can be a precedent in the development of architecture in the present. The concept of green architecture is now developed, traditionally have been implemented by indigenous peoples. Although the philosophy which is used as a based rationale of applied building rules to build and maintain the environment is not the modern concept rational. However, the sustainability of the village and their environment today is an example of sustainable architecture (barliana, 2012).

Exploration and study of architecture and environment of the indigenous peoples remains to be done and the most important is how the values of local wisdom and technical capabilities of indigenous peoples can be used as an example of modern architecture development. For modern life, the need to lift up the fact and value of local wisdom as a process enrich the knowledge, but the important thing is how the values of traditional community life can become an example for today's society (widaningsih, 2013). Thus, the reinterpretation of the treasure value and physical formation of their living space should not only be regarded as "memories" will last only history as the history of symbols and inscriptions

It required public education efforts that promote the values of local wisdom that has been embedded in indigenous peoples as a reference in maintaining people and environmental sustainability. Basically, the continuation of this research will try to apply the architectural precedent (transformation of architectural value) of indigenous villages on the object of study, namely Cibeureum village Cimalaka district of Sumedang regency. Educational activities to this communities had been pioneered by Een Sukaesih have a positive impact on society. Precedent of traditional village architecture covers various aspects of both physical (building techniques, materials used, the system environment) and non-physical concerning the strengthening of communities in developing their village.

The main problem of the study was formulated: How is the architectural precedent of traditional village in the modern architecture design? Aspects examined included, the values of architectural society education, building and site management, environmental site management, building technique (use of building materials and construction systems).

\section{B. Research Method}

Research will be carried out by paradigmatic frameworks as follows. 


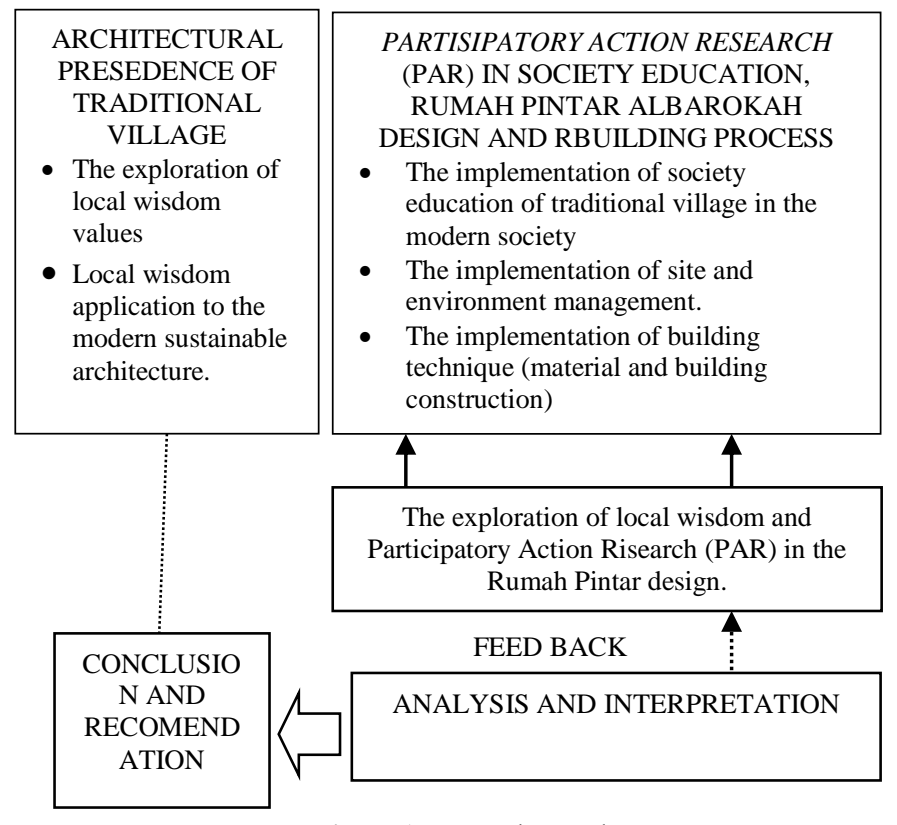

Figure 1. Research's road map

\section{RESEARCH RESULT}

\section{A. The application of society educational values of indigenous peoples in architecture}

In the tradition of architecture, Indonesia traditional community has its own characteristics which are an expression of the culture and traditions in their communities. But in general, the noble values own particularly in balancing the good life with the creator, fellow human beings and with nature has substantial similarity. The only difference in the way language represents and expresses. The balance of life of indigenous peoples in various parts such as "Memayu Hayuning Buwana" of the Java community, the concept of "Siger Tenang" for the Sundanese people or the concept of "Tri Hita Karana" of the Balinese. The representation of these values in life shows that people commit to maintain the balance of life with the natural environment is a necessity which is strictly regulated and adhered by society.

Life balance representation of the noble values of traditional societies provides many valuable life lessons. Not only for customary communities, but if it used as an education of life of wider society, will provide a useful value in maintaining the balance of life. However, the development of science and technology has a lot of shifting values and no longer a strong bond to the modern society. Access to information through a variety of media is the main factor that changed the way of life, system life and values in society.

How traditional society threats the nature must be able to educate modern people by the massages from the past. Architectural artefacts of traditional village contained many nobled community education values. These values should be formulated to apply in today's society.

The general philosophy of the valuable views that inheritable local tradition is still obtain positive response.
Residents still consider that ethics in maintaining a relationship between people is still very necessary. Most residents expressed their approval of asking permission when the building houses process, ask neighbors permission, village elders and formal governance remains to be done as a form of modesty and keeping the values of society.

However, related to the aesthetics values, community transition affected by modernity, cannot fully comply with the stipulated collective aesthetic value. It is different from the traditional societies that very obedient to the rules of form, beauty and other rules concerning environmental and buildings compatibility, people in the study area experienced a shift or loose to such problems Aesthetic value in residential buildings are viewed as " personal taste " unnecessary interpreted or regulated by the community. Thus concerns the building model, shape, size, material used is extremely varied in accordance with the wishes or individual tastes.
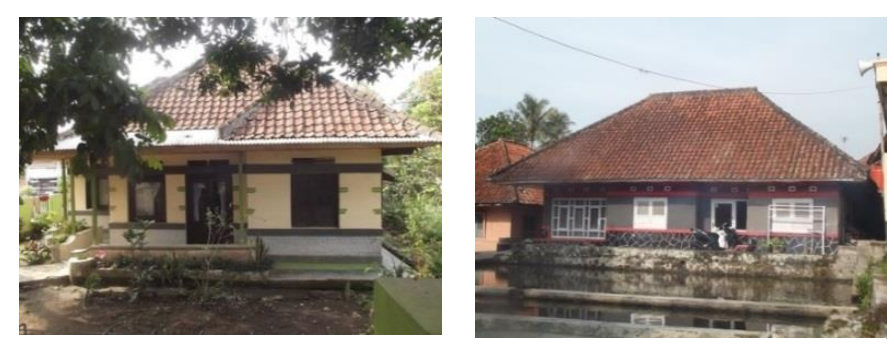

Figure 2. Permanent housing with colonial style shows the external influence in the building process is happened in a long time. Source: Research documentation, 2014
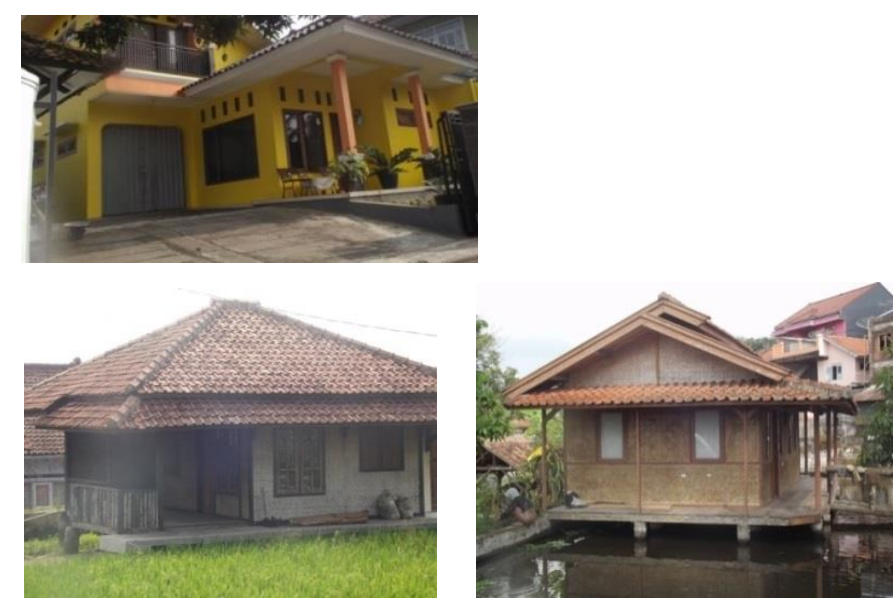

Figure 3. Sundanese traditional housing with wood and bamboo material used is still found even only a few Source: Research documentation, 2014

Some examples of houses in the study area can illustrate that various external influences including the value system into an inevitability that cannot be avoid. Most of them know the traditional rules and it values, but because of various information developed, many residents had left some of these rules. They prefer using rational considerations concerning the ease, the economic value and personal tastes.

Meanwihle, application of religious value is in religious building (mosque) that built by non-governmental. Precedence of traditional architecture appears in the form of the roof, the 
building and the terrace opening system that uses the concept of Sundanese traditional architecture.
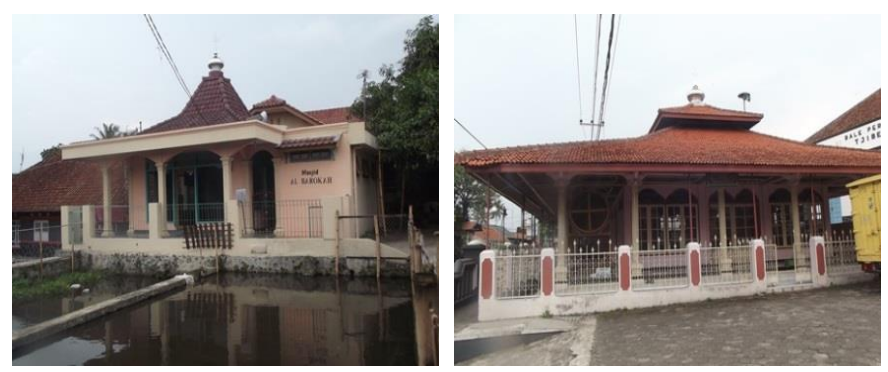

Figure 4. Non-govermental mosque

Source: Research documentation, 2014

Social values are regarding attention to others, how, habits, behavior patterns, customs and laws/rules that exist in society. Common values of the Indonesian such as rembug warga (residents meeting) is still done to discuss and decide to public problem solving.
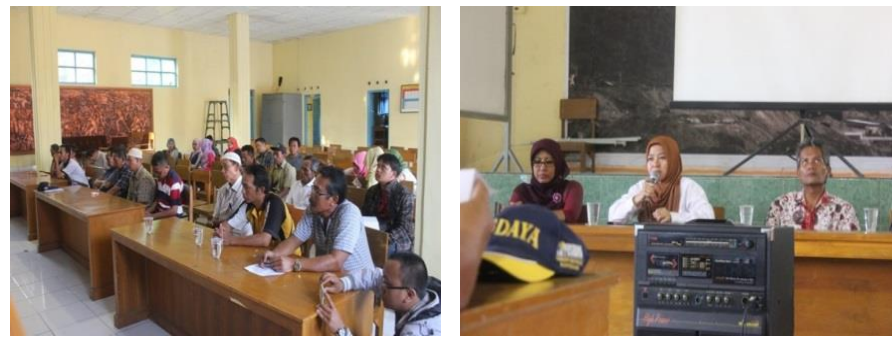

Figure 5. rembug warga (reseident meeting) in the planning, designing, and implementation building process of rumah pintar

Source: Research documentation, 2014

Forms of social relationships that exist in society has not fully demonstrate the character of rural community. Heterogeneous society with different educational and jobs backgrounds has been given its own color. Fully self-help traditions ranging from human resources and other resources began to shift.

The process of rembug warga through Focus Group Discussion facilitated by researchers only followed by some residents and in the building process there is the tendency of some residents and leaders do not actively participate. It shows the application of social values no longer fully applicable.

However, the general pattern of approach and mentoring as part of the implementation of the PAR method that is done to the community can build the concept of togetherness empowerment. On the other hand, it is not easy to re-apply architectural precedent of traditional villages in totality because the reality of people's culture has changed, even in rural communities.

\section{B. Application of Site Building and Environmental Management}

Cibeureum Wetan village is known as the center of freshwater fish planting such as carp, tilapia, carp and catfish. Most of the land is still made up of rice field and some residents still maintaining fish ponds on their land. People realized the natural potential and its benefit for welfare.

In the traditional village society, the building site and the environmental management is very strictly regulated by customary conditions, such as in the village of Naga which explicitly every activity physically separated. Residential function, a sacred area, service areas, production areas (fields, farms and forests) in an environment site should not be put together, each has own zone that should not be violated by the villagers. In the study area, physically, mutual function of site is found. There are paddies, fish ponds, and settlements in Cibeureum Wetan, but the separation is not based on custom rules. Personal rights owners so dominant and has the authority to regulate land fit and function of their needs. From the observations made, the increasing growth of the population, including migrants who live in the village Cibeureum Wetan. Many paddies areas have been converted to residential. On the other hand, the land value always high, so many villagers who prefer to sell their land to other parties.

One of the environmental education can be developed related to site and environmental management is to strengthen the habit of citizens who still maintain the existence of a fish pond as part of the yard. It can be developed the design of residential buildings with the construction of stilts houses above the fish pond. The researchers applied this in the design and construction of Rumah Pintar, where existing fish pond is maintained and functioned to serve needs of Rumah Pintar.

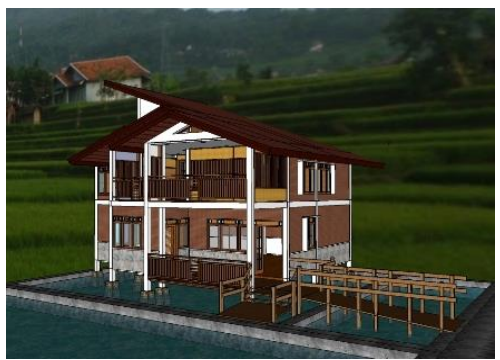

Figure 6. Early design of Ruma Pintar Al Barokah. Exploration of Sundanese tradisiona building concept Sources: Research documentation, 2014

\section{Application of Building Technique (use of building materials and construction systems)}

Traditional village in West Java such as Kampung Naga, Baduy, Ciptagelar, Kuta, and Dukuh, has a high cultural inheritance building technique. The use of local materials shows the pattern sustainable, natural preservation environmental friendly process and high knowledge of peoples about the kind of natural building materials that can be used in their buildings. Likewise, construction system of traditional building that are technically meet the rules of modern design, adaptation to local climate, the response to natural conditions 
(contour) as well as their local knowledge that has been able to build earthquake-friendly buildings.
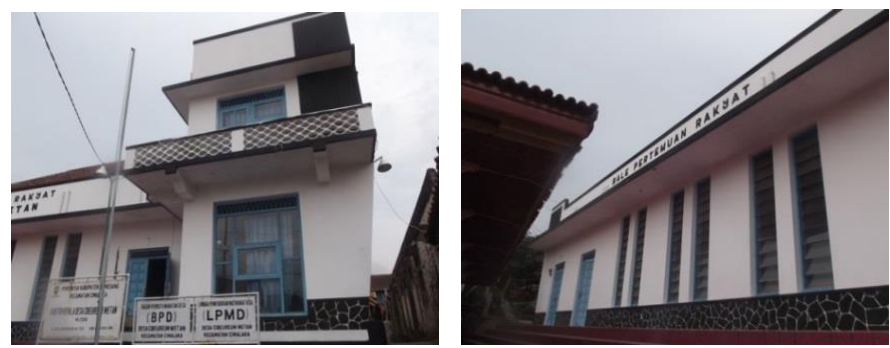

Figure 7 Community Center (Bale Desa) of Cibeureum Wetan, built by local worker in ' 70 s

Source: Research document, 2014

Technical capability building of the builders is a hereditary expertise developed by autodidact. Experience in developing and implementing a wide range of design influences causes rarely built a traditional house with construction system and natural materials. So there are some builders and citizens who consider the concept of a traditional building with natural materials is not efficient to do. On the other hand, there is a presumption that more permanent residential buildings showed a higher social status than a simple home

The dominant building in the village of Cibeureum Wetan is an evidence of the building technique capability of local builder has been established since the 70s, namely community center building that adopts the influence of colonial buildings.
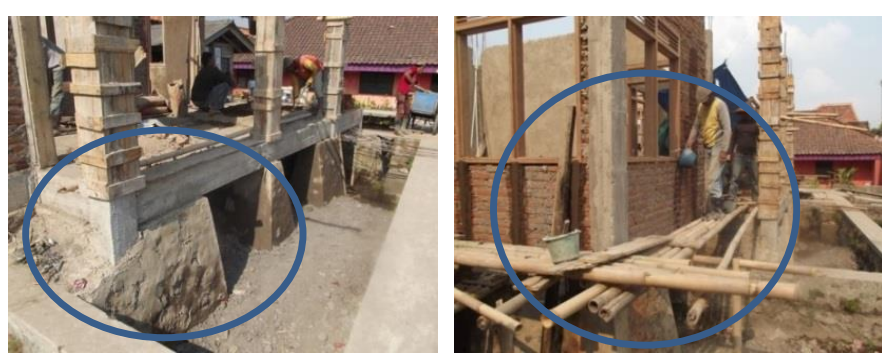

Figure 9. The stage house concept and optimalizing natural lighting is adopted from traditional building of Kampung Naga Source: Research documentaion, 2014

In the discussion process of planning and designing of Rumah Pintar, when the concept stage house with wood and bamboo materials is disclosed, most of the residents and builders refused because it was not meet the current needs. While the concept of houses on stilts above the fish pond with traditional building design more accepted. Building construction stage by utilizing the existing land a fish pond made part in educating people in their land management. Although the local materials material used is not possible to fully use, technically difficult to obtain too many builders and residents who prefer manufacturing materials that are considered cheaper and easier in the works.

Another problem is uneven ability of worker and undisciplined with the work time. The involvement of local artisans is an option to take advantage of local resources, but the selection of people based on "taste" and "interests" group of people have an impact on work patterns that are not maximum.

Technically, the design of the building does not have a high degree of difficulty, in addition to the roofing work that requires local expert carpenter. The carpenter abbility is quite high, so the explanation of design can be understood and done well. Education in the technical application of the Rumah Pintar building is how the design concept, the building functional needs and work patterns can be communicated by researchers, can be understood and worked by artisans.

\section{CONCLUSION}

The study of society educational values of indigenous peoples in architecture showed that life balance representation of the noble values of traditional societies provides many valuable life lessons. However, the development of science and technology are shifting the values and no longer strong ties to the community, even in the countryside.

Meanwhile, in the aspect of ethical values in maintaining the relationship between people is still very necessary. Most of the residents in the study area declared their agreement for asking permission of neighbors, village elders and formal governance remains to be done as a form of modesty and keeping the values of society. However, in relation to the values related to aesthetics, people who are already affected by the transition to modernity, can not fully comply with the aesthetic value is set collectively. Aesthetics of the building has become a choice invidual and regarded as personal tastes freely adopt the values of beauty of various influences.

In the study of sites building and environmental management, physically, there is an area which has the same function as in the traditional village. Namely, the paddies, fish ponds, and settlements, but the separation is not based on custom rules. Personal rights owners so dominant and has the authority to regulate land fit and function of their needs. One of the environmental education that can be developed related to site and environmental management is to strengthen the habit of citizens who still maintain the existence of a fish pond as part of the yard.

In term of building technique application, it showed that the technical ability to build of the builders possessed a hereditary expertise developed autodidact. The existing generation of builders is now rarely get a job to build a traditional house with system construction and natural materials. It because experience in developing and implementing a wide range of design influences. Some builders and citizens who consider the concept of a traditional building with natural materials are not efficient to do. On the other hand, there is a presumption that more permanent residential buildings showed a higher social status than a 
simple house. Education in the technical application of the Rumah Pintar building is how the design concept, the building functional needs and work patterns can be communicated by researchers, can be understood and worked by artisans.

\section{REFERENCES}

[1] Altman, Irwin \& Martin Chemers, "Culture and Environment". California: Wadswoth, Inc., 1984

[2] Barliana, M. Syaom, "Tradisionalitas dan Modernitas Tipologi Arsitektur Masjid”, Bandung: Metatekstur Penerbit Diskursus, 2010.

[3] Barliana, dkk, "Pola Pembelajaran Pewarisan Tradisi Arsitektur Berkelanjutan”, Penelitian Etnopedagogi, UPI, 2012
[4] Firmansyah, "Arsitektur berkelanjtan dan Arsitektur Hijau”, UNIKOMBnadung, 2011

[5] Hamka Naping, "Kelembagaan Tradisional dan Kearifan Lokal dalam Pengelolaan Lingkungan pada Masyarakat Toraja. Makassar" : PPLH Regional Sulawesi Selatan, Maluku dan Papua KLH bekerjasama dengan Masagena Press, 2007

[6] Nababan, A., "Kearifan Tradisional dan Pelestarian Lingkungan Hidup di Indonesia”. Dalam Analisis CSIS November-Desember Tahun XXIV No.6 : 42-435, 1995

[7] Prawoto, Eko, "Arsitektur Yang Memberi". Avaliaable at: http://www.housing-estate.com/index.php, 2010 